\title{
Groundnut (Arachis hypogaea L.) varietal response to spacing in the Guinea Savanna agro-ecological zone of Ghana: Nodulation and nitrogen fixation.
}

\author{
Konlan, S, Sarkodies-Addo, J,. Asare, E and Kombiok, M. J \\ KONLAN Sampson, Cocoa Research Institute of Ghana, P. O. Box 8, New Tafo-Akim, \\ Eastern Region, Ghana.
}

\begin{abstract}
An experiment was conducted at the Savanna Agricultural Research Institute (SARI) to determine the response of groundnut varieties to spacing with regard to nodulation and nitrogen fixation. The randomized complete block (RCB) experiment with three replicates used six varieties and three spacing arrangements. The Nkosuor variety recorded $2.1 \%$ and $3.5 \%$ residue and seed nitrogen respectively, ultimately giving the highest total fixed plant nitrogen in 2007 . This, coupled with the large stover yield by Nkosuor resulted in the largest stover $N$ of $53.8 \mathrm{~kg} \mathrm{~N} \mathrm{ha}^{-1}$ in 2007 . The Jenkaar variety which recorded the largest two year average for stover yield subsequently recorded the largest two year average for stover N. The SP2 $(40 \times 10 \mathrm{~cm})$ arrangement supported significant stover yield and stover N in 2006 while the SP1 $(30 \times 15 \mathrm{~cm})$ arrangement produced the largest stover yield and $\mathrm{N}$ in 2007 , recording a two year stover $\mathrm{N}$ average of $42.1 \mathrm{~kg}$ $\mathrm{N} \mathrm{ha}{ }^{-1}$. Based on the two year average performance, the Jenkaar variety was found to be superior in terms of nitrogen fixation. However, more benefits would be derived if the variety is established using the SP1 arrangement under sole groundnut system.
\end{abstract}

Keywords: Rhizobia, rudimentary, stubble, smother, solubilize.

\section{INTRODUCTION}

Extensive cereal cultivation with little or no fertilizer input, coupled with annual bushfires that remove the vegetation cover including crop stubble in the Guinea savanna has resulted in a decline in soil fertility. Farmers therefore have to shift to relatively new and more fertile lands or increase the area under cultivation to meet the same production targets. These systems face serious challenges as demand for land increases because of extensive farming practices for other crops and competing nonagricultural land uses. Added to these is the huge cost of cultivating large spans of land with rudimentary farm tools.

Among the several legumes planted in the Guinea savanna of Ghana, groundnut by far is the most important, usually grown as cash crop. The added benefit groundnut brings to the agricultural production systems through biological nitrogen fixation have been well studied and documented (Linderman and Glover, 2008; Toomson et al., 1995). Grain legumes like groundnut have been reported to provide an equivalent of $60 \mathrm{~kg} \mathrm{~N}^{-1}$ to subsequent non-legume crop (Ghosh et al., 2007). There have been several reports of increased production of cereal following groundnut in the crop sequence (Ghosh et al., 2004a). Bado et al., (2006) reported that lower doses of $\mathrm{N}\left(20 \mathrm{~kg} \mathrm{~N}\right.$ ha $\left.^{-1}\right)$ fertilizer were required by sorghum following groundnut compared to sorghum following cowpea (60 $\left.\mathrm{kg} \mathrm{N} \mathrm{ha}^{-1}\right)$ to achieve the same yield results. Similarly, wheat which followed groundnut recorded higher grain yield than that following pearl millet (Ghosh et al., 2007). In a fodder legume experiment, the carry-over of $\mathrm{N}$ from groundnut for use by the succeeding crop was found to be $54-58 \mathrm{~kg} \mathrm{~N} \mathrm{ha}^{-1}$ (Hedge and Dwivedi, 1993).

The benefits of groundnut as a legume is not limited to sole groundnut systems. Cereals have been reported to benefit significantly in cereal/groundnut intercropping systems through direct transfer or the process of nitrogen sparing, as well as enjoying other benefits associated with the presence of nitrogen fixing bacteria in the soil (Nambiar and Dart, 1980). Results of intercropping study by Rwamugira and Massawe (1990) showed that maize intercropped with groundnut responded to fertilizer up to $60 \mathrm{~kg} \mathrm{~N}$ $\mathrm{ha}^{-1}$ while sole maize responded up to $120 \mathrm{~kg} \mathrm{~N} \mathrm{ha}^{-1}$. In nitrogen uptake study of intercropped maize and groundnut, it was observed that at low nitrogen levels, the nitrogen content of intercropped maize 
Agric. Biol. J. N. Am., 2012, 4(3):324-335

was higher than that of sole maize, indicating some transfer of fixed $\mathrm{N}$ from the groundnut to maize (Francis, 1986). Earlier studies by Nair et al., (1979) had shown that groundnut/maize intercropping system increased the nitrogen uptake and yield of succeeding wheat crop, and intercropping sorghum with groundnut reportedly reduced the nitrogen fertilizer requirement of the succeeding wheat crop by $30-84 \mathrm{~kg} \mathrm{~N} \mathrm{ha}^{-1}$ over sole sorghum. In the case of Ghosh et al., (2007), the N requirements of wheat for a target yield of 4.0 tha $^{-1}$ was $100.8 \mathrm{~kg} \mathrm{ha}^{-1}$ after sole sorghum, which was reduced to $83 \mathrm{~kg} \mathrm{ha}^{-1}$ after intercropping sorghum with groundnut.

In legume/legume intercropping, practiced largely in India, the predominant intercropping system is pigeon pea/groundnut system found in most parts of dry land areas because of the ability of groundnut to establish rapid canopy cover over the ground and efficiently utilize growth resources (Ghosh et al., 2007). Also, groundnut included in the cropping system is known to help solubilize insoluble $P$ in the soil, improve the soil physical environment, increase soil microbial activity, restore organic matter and smother weeds (Ghosh et al., 2007). This study therefore sought to investigate the contributions of new groundnut varieties and close spacing to biological nitrogen fixation in the Guinea savanna agro-ecology of Ghana.

\section{MATERIALS AND METHODS}

Experimental site: The experiment was conducted in 2006 and 2007 on the research station of the savanna agricultural research institute (SARI) at Nyankpala. Nyankpala $\left(9^{\circ} 25^{\prime} \mathrm{N}, 1^{\circ} 00^{\prime} \mathrm{W}, 183\right.$ metres above sea level) is a farming community located 16 $\mathrm{km}$ west of Tamale. The land has a gentle slope of about $2 \%$ and is strongly disturbed by sheet erosion. It is a well drained Voltaian sandstone soil unit locally referred to as Tingoli series. The field was left fallow for three years after being cropped to maize previously. The initial analysis of soil samples taken at the site revealed a $\mathrm{pH}$ of 6.5 in calcium chloride $\left(\mathrm{CaCL}_{2}\right), 0.044 \%$ total nitrogen, $10.5 \mathrm{mg} \mathrm{kg}^{-1}$ available $\mathrm{P}$ and $0.37 \%$ organic carbon.

The climate is warm, semi-arid with mono-modal annual rainfall of up to $1200 \mathrm{~mm}$ which falls mostly between May and September. This is then followed by seven months of dry season, which is characterized by the dry harmattan winds with high risk of uncontrolled bushfires resulting in the loss of vegetative cover. The average monthly atmospheric temperatures range from $26{ }^{\circ} \mathrm{C}$ to a maximum of 39
${ }^{0} \mathrm{C}$ with an annual mean of $32{ }^{\circ} \mathrm{C}$. The total amount of rainfall during the period of the experiment in 2007 was $873.5 \mathrm{~mm}$ which was higher but less evenly distributed than the rainfall of $740.4 \mathrm{~mm}$ received during the same period in 2006.

Experimental Design and Treatments: The experiment was laid out in randomized complete block (RCB) design with three replicates. Each plot measured $6 \mathrm{~m} \times 6 \mathrm{~m}$. A net plot which measured $4 \mathrm{~m}$ $x 4 \mathrm{~m}$ was taken for crop growth data and yield analysis. The factors tested were groundnut variety and plant spacing. These comprised six varieties (Adepa, Azivivi, Jenkaar, Nkosuor, Kpanieli and Manipintar) and three different spacing (SP1 (30 x 15 $\mathrm{cm})$; SP2 $(40 \times 10 \mathrm{~cm})$ and SP3 $(50 \times 10 \mathrm{~cm}))$. Initial weed control was by hand hoe and hand pulling 3 and 6 weeks after planting respectively.

\section{Plant measurements}

Plant stand and number of branches: Plant count was done two weeks after sowing from each net plot. The number of branches of five selected and tagged plants from each net plot was also determined by counting at maturity. The data was then subjected to square root transformations.

Shoot dry matter: From the border rows on each side of each treatment plot, five plants were randomly chosen and cut at the ground level for shoot dry matter determination 4, 6 and 8 weeks after planting (WAP). Total fresh weight was taken using an electronic balance in the laboratory of SARI in 2006 and 2007. Plant materials were then put in large brown envelopes and oven dried at $80{ }^{\circ} \mathrm{C}$ for 72 hours. The dry material was then weighed and shoots dry matter recorded.

Number of nodules: Five plants from the border rows were randomly selected and gently dug out 6 weeks after sowing. The plants were then washed through a fine sieve in water to remove soil particles. The number of nodules on each plant was then determined and the average nodule number per plant calculated. Data was then subjected to square root transformation.

Estimation of percent nitrogen fixed and stover nitrogen: The technique used to estimate $\mathrm{N}_{2}$-fixed was the Total Nitrogen Difference (TND) method as described by Hansen (1994). The groundnut varieties and spacing treatments were compared to a single treatment of maize (Dorke SR) per replication, grown as the reference crop. To measure nitrogen fixation, residue and seed samples of both the groundnut 
varieties and the reference crop were ground and crude protein content was obtained using the microKjeldahl method. Nitrogen content was measured by automated indophenols method and was read on flow injection analyzer (FIA). The nitrogen difference between the groundnut treatments and the maize crop on per plant basis was regarded as the quantity of $\mathrm{N}$ provided by biological nitrogen fixation (BNF).

Thus $\mathrm{N}_{2}-$ fixed $=$ Nyield $_{\mathrm{fix}}-$ Nyield $_{\text {ref }}$

$\% \mathrm{Ndfa}=100\left(\right.$ Nyield $_{\mathrm{fix}}-$ Nyield $\left._{\mathrm{ref}}\right) /$ Nyield $_{\mathrm{fix}}$

Where;

$\mathrm{N}_{2}$-fixed=nitrogen fixed

$\% \mathrm{Ndfa}=$ percentage of plant nitrogen derived from atmosphere

Nyield ${ }_{\text {fix }}=$ nitrogen yield by $\mathrm{N}_{2}$-fixing system

Nyield ${ }_{\text {ref }}=$ nitrogen yield by reference crop (maize)

Stover $\mathrm{N}$ was then determined as;

$\mathrm{N}_{\text {stover }}=\mathrm{N}_{\text {residue }} / 100 \times \mathrm{Y}_{\text {stover }}$
Where;

$\begin{array}{lll}\mathrm{N}_{\text {stover }}= & \text { stover nitrogen }\left(\mathrm{kg} \mathrm{N} \mathrm{ha}^{-1}\right) \\ \mathrm{N}_{\text {residue }}= & \text { residue nitrogen }(\%) \\ \mathrm{Y}_{\text {stover }}= & \text { stover yield }\left(\mathrm{kg} \mathrm{ha}^{-1}\right)\end{array}$

Statistical methods: The data collected were subjected to statistical analysis using Genstat discovery edition (2011). The analysis of variance method was followed to determine whether differences existed among treatments. All treatments were compared using the least significant difference (Lsd) method at $5 \%$ probability level (Gomez and Gomez, 1984).

\section{RESULTS}

Plant stand, number of branches and nodules: There were no significant influence of both groundnut variety and spacing arrangement (transformed) on plant stand and, numbers of branches and nodules per plant in both cropping seasons (Table 1).

Table i. Plant stand, number of branches and nodules per plant as affected by groundnut variety and spacing arrangement.

\begin{tabular}{|c|c|c|c|c|c|c|}
\hline \multirow[b]{2}{*}{ Variety } & \multicolumn{2}{|c|}{ Plant stand $\left(\mathrm{m}^{2}\right)$} & \multicolumn{2}{|c|}{ No. of branches } & \multicolumn{2}{|c|}{ No. of Nodules } \\
\hline & 2006 & 2007 & 2006 & 2007 & 2006 & 2007 \\
\hline Adepa & $19.1(4.4)$ & $19.5(4.4)$ & $13.2(3.6)$ & $11.2(3.3)$ & $199.8(14.1)$ & $107.4(10.4)$ \\
\hline Azivivi & $12.9(3.6)$ & $19.2(4.4)$ & $13.3(3.6)$ & $12.0(3.5)$ & $214.7(14.7)$ & $139.4(11.8)$ \\
\hline Jenkaar & $13.8(3.7)$ & $19.7(4.4)$ & $13.0(3.6)$ & $11.8(3.4)$ & $206.1(14.4)$ & $154.6(12.4)$ \\
\hline Kpanieli & * & $18.5(4.3)$ & * & $10.5(3.2)$ & * & $174.9(13.2)$ \\
\hline Nkosuor & $19.1(4.4)$ & $18.7(4.5)$ & $13.7(3.7)$ & $11.8(3.4)$ & $216.7(14.7)$ & $163.9(12.8)$ \\
\hline Manipintar & * & $20.1(4.5)$ & * & $11.4(3.4)$ & * & $201.2(14.2)$ \\
\hline $\operatorname{Lsd}_{0.05}$ & ns & ns & ns & ns & ns & ns \\
\hline Spacing & & & & & & \\
\hline $30 \times 15 \mathrm{~cm}$ & $17.2(4.1)$ & $19.0(4.4)$ & $11.9(3.5)$ & $12.0(3.5)$ & $209.4(14.5)$ & $156.4(12.5)$ \\
\hline $40 \times 10 \mathrm{~cm}$ & $17.0(4.1)$ & $20.7(4.5)$ & $13.4(3.7)$ & $11.5(3.4)$ & $209.0(14.5)$ & $159.4(12.6)$ \\
\hline $50 \times 10 \mathrm{~cm}$ & $14.5(3.8)$ & $18.2(4.3)$ & $14.6(3.8)$ & 10.9 (3.3) & $209.6(14.5)$ & $154.9(12.4)$ \\
\hline $\operatorname{Lsd}_{0.05}$ & ns & ns & ns & ns & ns & ns \\
\hline CV (\%) & 2.6 & 5.7 & 1.4 & 6.1 & 4.8 & 8.4 \\
\hline
\end{tabular}

Note: Values in parenthesis are square root transformations. ${ }^{*}$ No data taken in that year. ns $=$ No significant difference

Shoot dry matter: The shoot dry matter recorded by Azivivi and Jenkaar were similar 4, 6 and 8 WAP in 2006 (Fig 1.1) but the effect of either variety on shoot dry matter was significantly $(P<0.05)$ different from the effect of the Nkosuor variety. In 2007, effect of the Manipintar variety on shoot dry matter was significantly higher $(\mathrm{P}<0.05)$ than those of Azivivi and Nkosuor varieties at 4 WAP (Fig 1.3). Spacing did not significantly influence shoot dry matter in both years (Fig 1.2 and 1.4). 
Agric. Biol. J. N. Am., 2012, 4(3):324-335

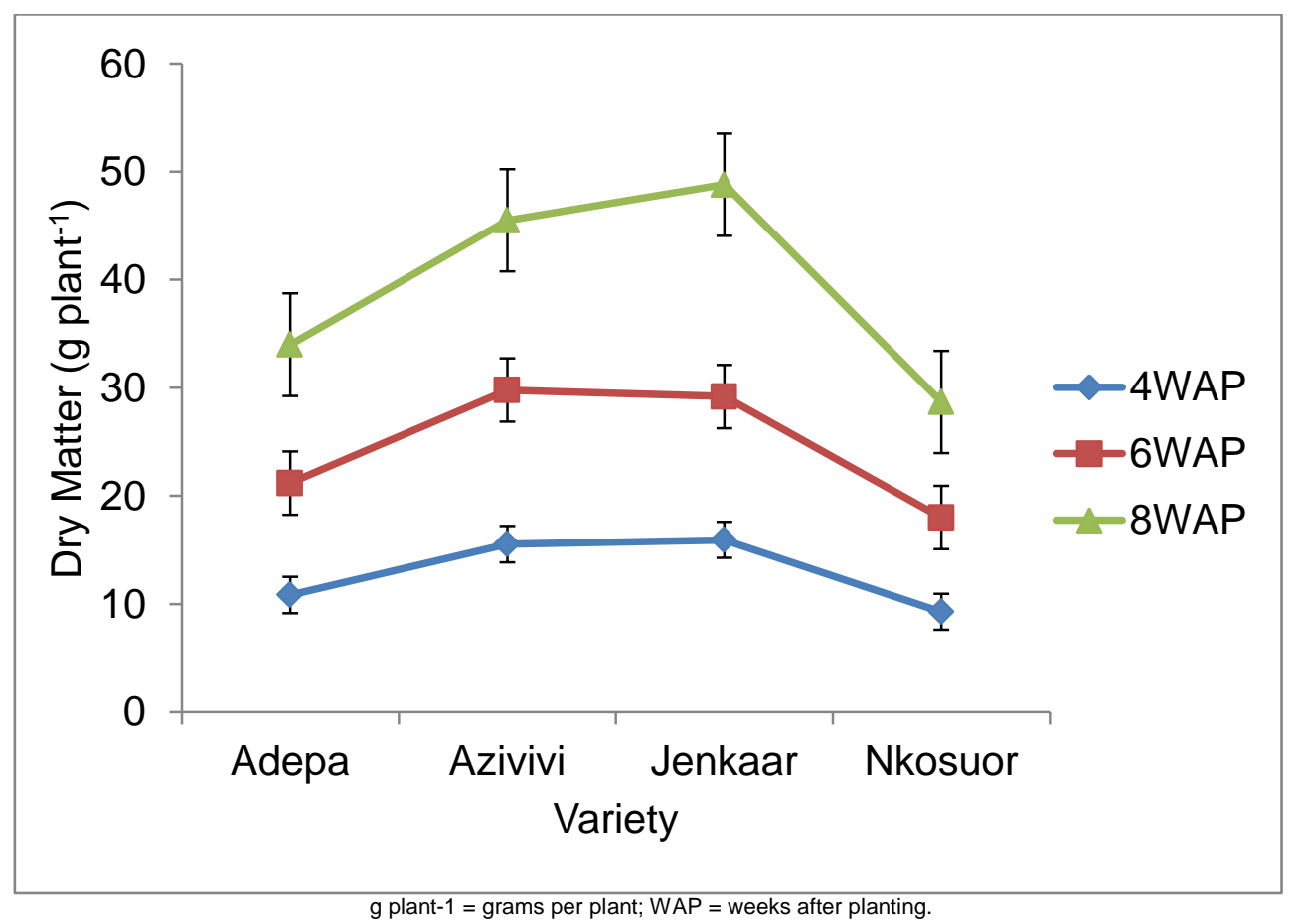

Fig 1.1 Above ground dry matter per plant, taken 4, 6 and 8 weeks after planting as affected by variety in 2006.

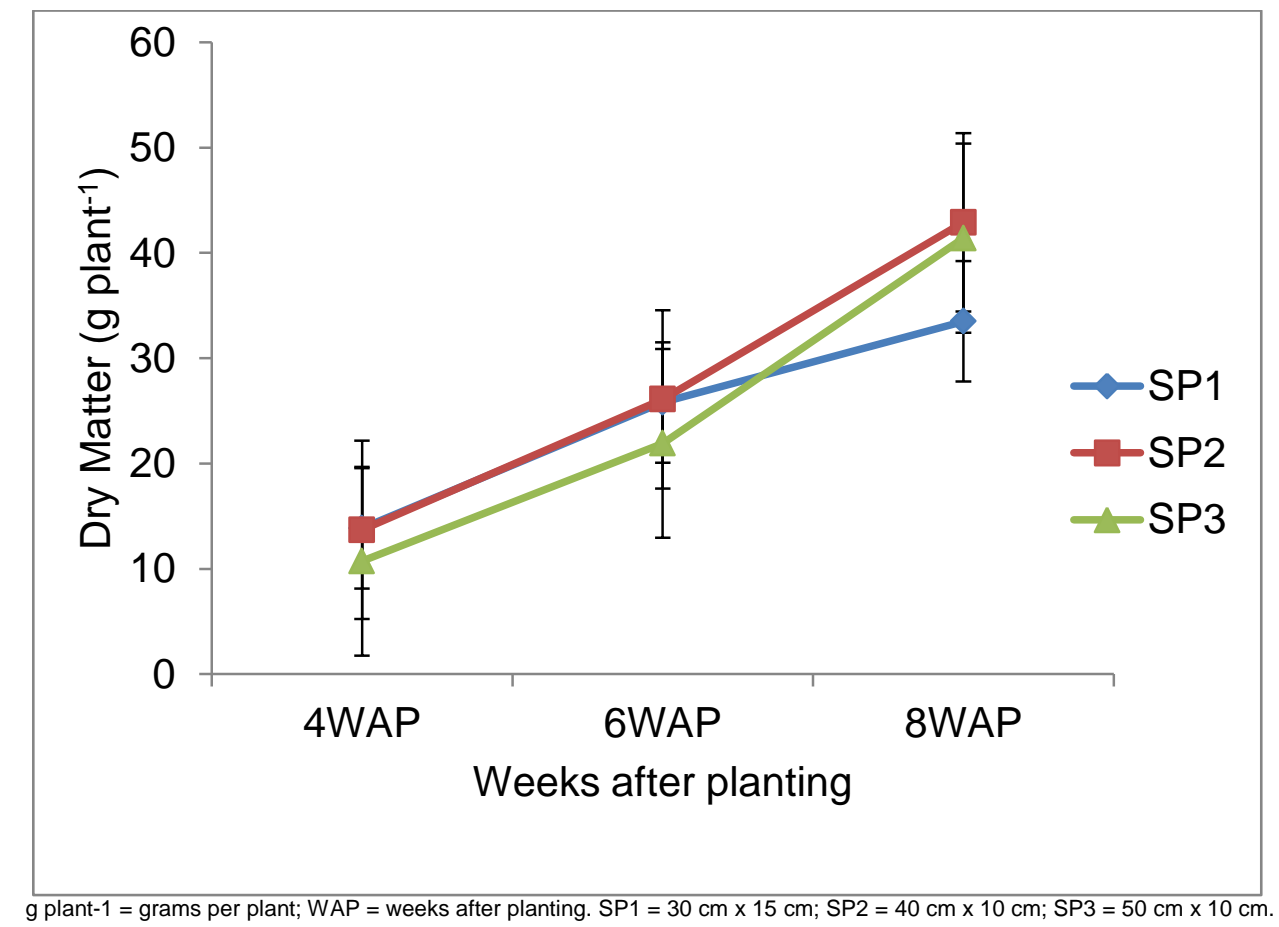

Fig 1.2 Above ground dry matter per plant 4, 6 and 8 WAP as affected by spacing arrangement in 2006. 
Agric. Biol. J. N. Am., 2012, 4(3):324-335

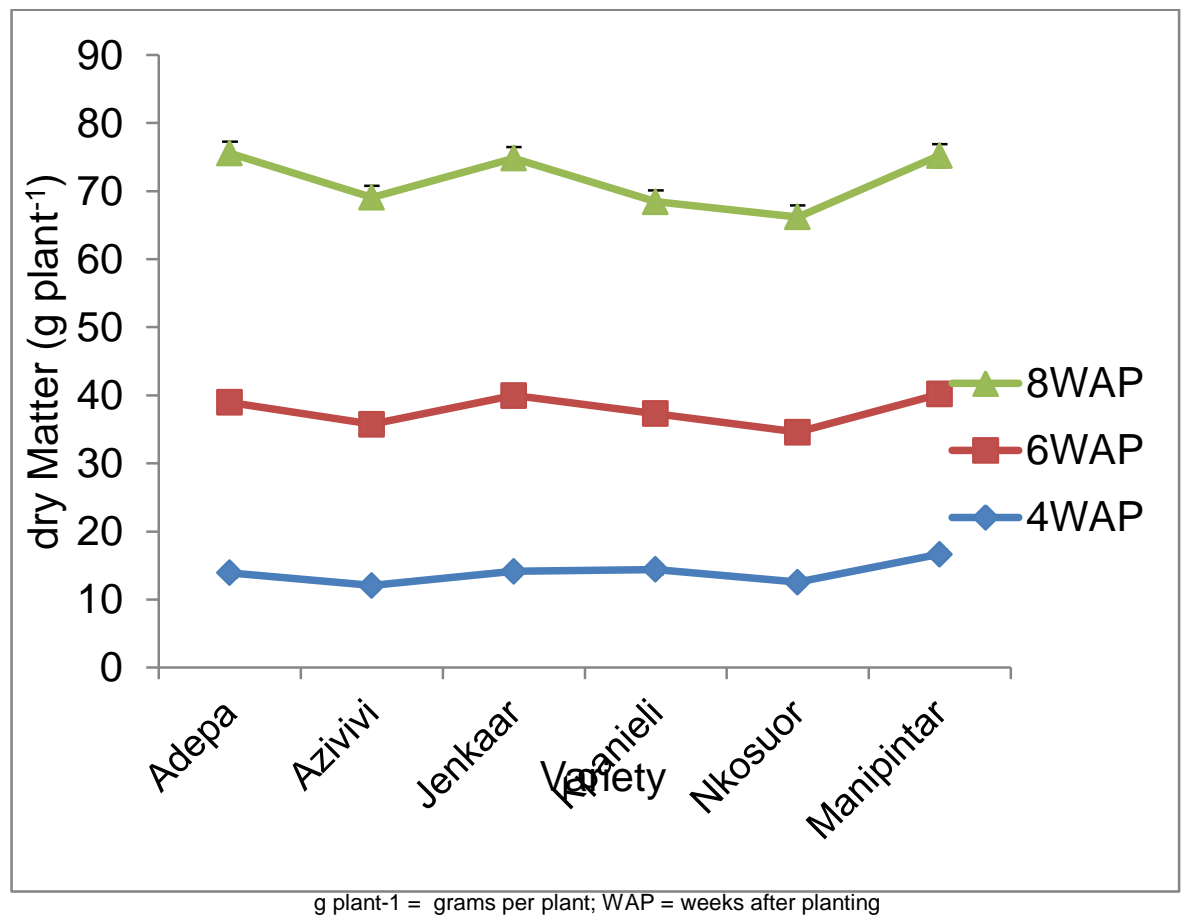

Fig 1.3 Above ground dry matter per plant, taken 4, 6 and 8 weeks after planting as affected by variety in 2007.

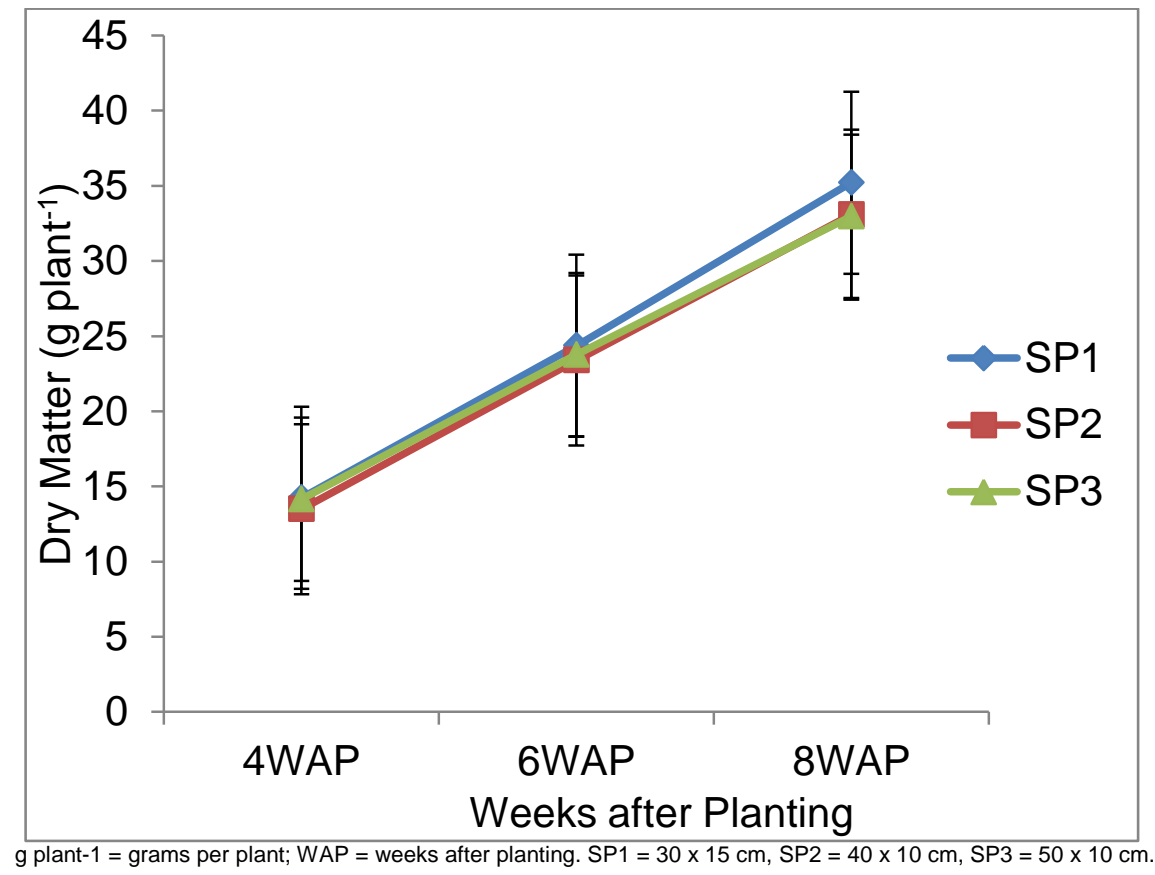

Fig 1.4 Above ground dry matter per plant 4, 6 and 8 WAP as affected by spacing arrangement in 2007. 
Percent residue, seed and total nitrogen: The effect of the Adepa variety on residue N in 2006 was significantly more $(P<0.05)$ than the effect of the Nkosuor variety. In 2007, effects of the Manipintar and Nkosuor varieties on residue $\mathrm{N}$ were similar but either effect was significantly higher $(P<0.05)$ than those of the remaining varieties which recorded similar effects (Table ii). The effect of Azivivi on seed $\mathrm{N}$ was significantly lower $(\mathrm{P}<0.05)$ than those of the remaining varieties which had similar effects (Table ii). The results also show that Nkosuor and Manipintar recorded similar effects on total N in 2007, however, the effect of Nkosuor was significantly higher $(P<0.05)$ than all other varietal effects (Table ii). Also, the effect of Manipintar on total $\mathrm{N}$ was significantly higher $(P<0.05)$ than the Adepa, Azivivi and Jenkaar varieties, all of which recorded similar effects on total $\mathrm{N}$.

Table ii. Residue, seed and total nitrogen as affected by groundnut variety and spacing arrangement.

\begin{tabular}{|l|c|c|c|c|c|c|}
\hline \multirow{2}{*}{ Variety } & \multicolumn{2}{|c|}{$\begin{array}{c}\text { Residue N } \\
(\%)\end{array}$} & \multicolumn{2}{c|}{ Seed N (\%) } & \multicolumn{2}{c|}{ Total N (\%) } \\
\cline { 2 - 7 } & 2006 & 2007 & 2006 & 2007 & 2006 & 2007 \\
\hline Adepa & 1.86 & 1.67 & 3.28 & 3.17 & 5.14 & 4.84 \\
\hline Azivivi & 1.60 & 1.42 & 2.86 & 2.64 & 4.45 & 4.05 \\
\hline Jenkaar & 1.75 & 1.55 & 2.91 & 3.15 & 4.66 & 4.70 \\
\hline Kpanieli & $*$ & 1.49 & $*$ & 3.44 & $*$ & 4.93 \\
\hline Nkosuor & 1.49 & 2.02 & 3.39 & 3.47 & 4.86 & 5.49 \\
\hline Manipintar & $*$ & 1.96 & $*$ & 3.37 & $*$ & 5.33 \\
\hline Lsd 0.05 & $\mathrm{~ns}$ & 0.27 & $\mathrm{~ns}$ & 0.45 & $\mathrm{~ns}$ & 0.49 \\
\hline Spacing & & & & & & \\
\hline $30 \times 15 \mathrm{~cm}$ & 1.74 & 1.69 & 3.19 & 3.33 & 4.93 & 5.02 \\
\hline $40 \times 10 \mathrm{~cm}$ & 1.74 & 1.70 & 2.71 & 3.05 & 4.45 & 4.75 \\
\hline $50 \times 10 \mathrm{~cm}$ & 1.54 & 1.65 & 3.43 & 3.24 & 4.97 & 4.88 \\
\hline Lsd 0.05 & $\mathrm{~ns}$ & $\mathrm{~ns}$ & $\mathrm{~ns}$ & $\mathrm{~ns}$ & $\mathrm{~ns}$ & $\mathrm{~ns}$ \\
\hline data not taken in that year, $\mathrm{N}(\%)=$ percent nitrogen, ns = no signticant difference,
\end{tabular}

Stover yield and stover nitrogen: The Jenkaar variety supported the largest stover yield in 2006 and its effect was significantly higher $(\mathrm{P}<0.05)$ than the effects of the remaining varieties (Table iii). The Azivivi and Nkosuor varieties recorded similar effects on stover yield but the effect of the Nkosuor variety was significantly lower $(\mathrm{P}<0.05)$ than that of Adepa. In 2007, Manipintar and Nkosuor varieties recorded similar effects on stover yield each of which was significantly higher $(\mathrm{P}<0.05)$ than the effects of the remaining varieties. The effect of the SP3 spacing on stover yield in 2006 was significantly lower $(P<0.05)$ than the effects of the SP2 and SP1 spacing arrangements which recorded similar effects (Table iii). In 2007, the effect of the SP1 spacing on stover yield was significantly greater $(P<0.05)$ than the effects of SP2 and SP3 spacing arrangements. Also, effect of the SP2 spacing was significantly greater $(P<0.05)$ than effect of the SP3 spacing (Table iii). Stover $\mathrm{N}\left(\mathrm{kg} \mathrm{N} \mathrm{ha}^{-1}\right)$ in 2006 was greatest in the Jenkaar variety, and its effect was significantly higher $(P<0.05)$ than the effect of the Nkosuor variety only. In 2007, the Manipintar and Nkosuor varieties recorded similar effects on stover N. Varietal effect of Nkosuor on stover $\mathrm{N}$ was however significantly greater $(P<0.05)$ than the effects of the remaining varieties (Table iii). The effects of the SP1 and SP2 spacing arrangements on stover $\mathrm{N}$ in 2007 were similar but either effect was significantly $(P<0.05)$ different from the effect of the SP3 spacing (Table iii).

Table iii. Stover yield and fixed stover nitrogen as affected by groundnut variety and spacing arrangement.

\begin{tabular}{|l|c|c|c|c|c|}
\hline \multirow{2}{*}{ Variety } & \multicolumn{2}{|c|}{ Stover yield $\left(\right.$ tha $\left.^{-1}\right)$} & \multicolumn{3}{|c|}{ Stover N $\left(\mathrm{kg} \mathrm{N} \mathrm{h}^{-1}\right)$} \\
\cline { 2 - 6 } & 2006 & 2007 & 2006 & 2007 & $2 \mathrm{Yr} \mathrm{Av}$ \\
\hline Adepa & 1.642 & 2.158 & 31.1 & 35.2 & 33.5 \\
\hline Azivivi & 1.872 & 2.490 & 29.3 & 35.3 & 32.1 \\
\hline Jenkaar & 2.417 & 2.414 & 43.8 & 37.3 & 40.6 \\
\hline Kpanieli & - & 2.055 & - & 39.4 & $39.4^{*}$ \\
\hline Nkosuor & 1.327 & 2.842 & 20.1 & 53.8 & 37.0 \\
\hline Manipintar & - & 2.666 & - & 43.9 & $43.9^{*}$ \\
\hline Lsd ${ }^{0.05}$ & 0.4 & 0.4 & 21.9 & 10.4 & \\
\hline Spacing & & & & & \\
\hline $30 \times 15 \mathrm{~cm}$ & 2.014 & 2.873 & 36.6 & 47.6 & 42.1 \\
\hline $40 \times 10 \mathrm{~cm}$ & 2.192 & 2.485 & 38.0 & 42.6 & 40.3 \\
\hline $50 \times 10 \mathrm{~cm}$ & 1.238 & 1.955 & 18.7 & 32.2 & 20.5 \\
\hline Lsd ${ }^{0.05}$ & 0.4 & 0.3 & 18.9 & 7.1 & \\
\hline CV (\%) & 5.6 & 9.8 & 7.7 & 20.5 & \\
\hline -data not taken in that year, "one year stover N value &
\end{tabular}

Correlation analysis: Groundnut varieties and spacing arrangements exerted significant influences on residue $\mathrm{N}$ and stover $\mathrm{N}$ and their relationships in both years. Residue $\mathrm{N}$ was positive and highly correlated (Fig 1.5 and 1.6) to stover $\mathrm{N}$ of varieties $(\mathrm{r}$ $=0.63, P<0.05)$ and spacing arrangements $(r=0.53$, $P<0.05)$. The influences exerted by both variety and spacing arrangements on the relationship between stover yield and stover $\mathrm{N}$ were also positive and significant in both years (Fig 1.7, 1.8, 1.9 and 1.10). 
Agric. Biol. J. N. Am., 2012, 4(3):324-335

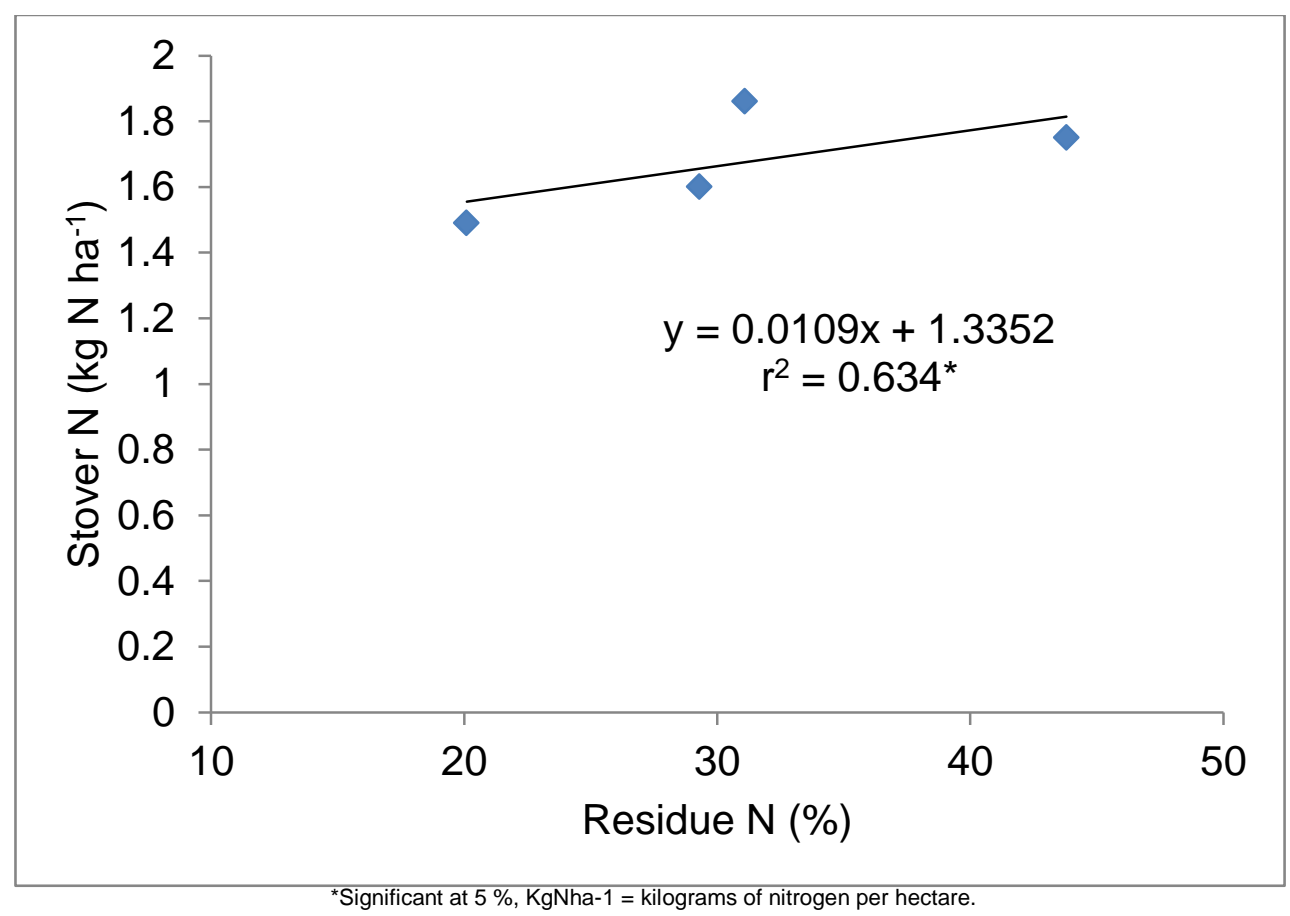

Fig 1.5 Relationship between residue $\mathrm{N}$ and stover $\mathrm{N}$ as affected by spacing arrangement in 2006 .

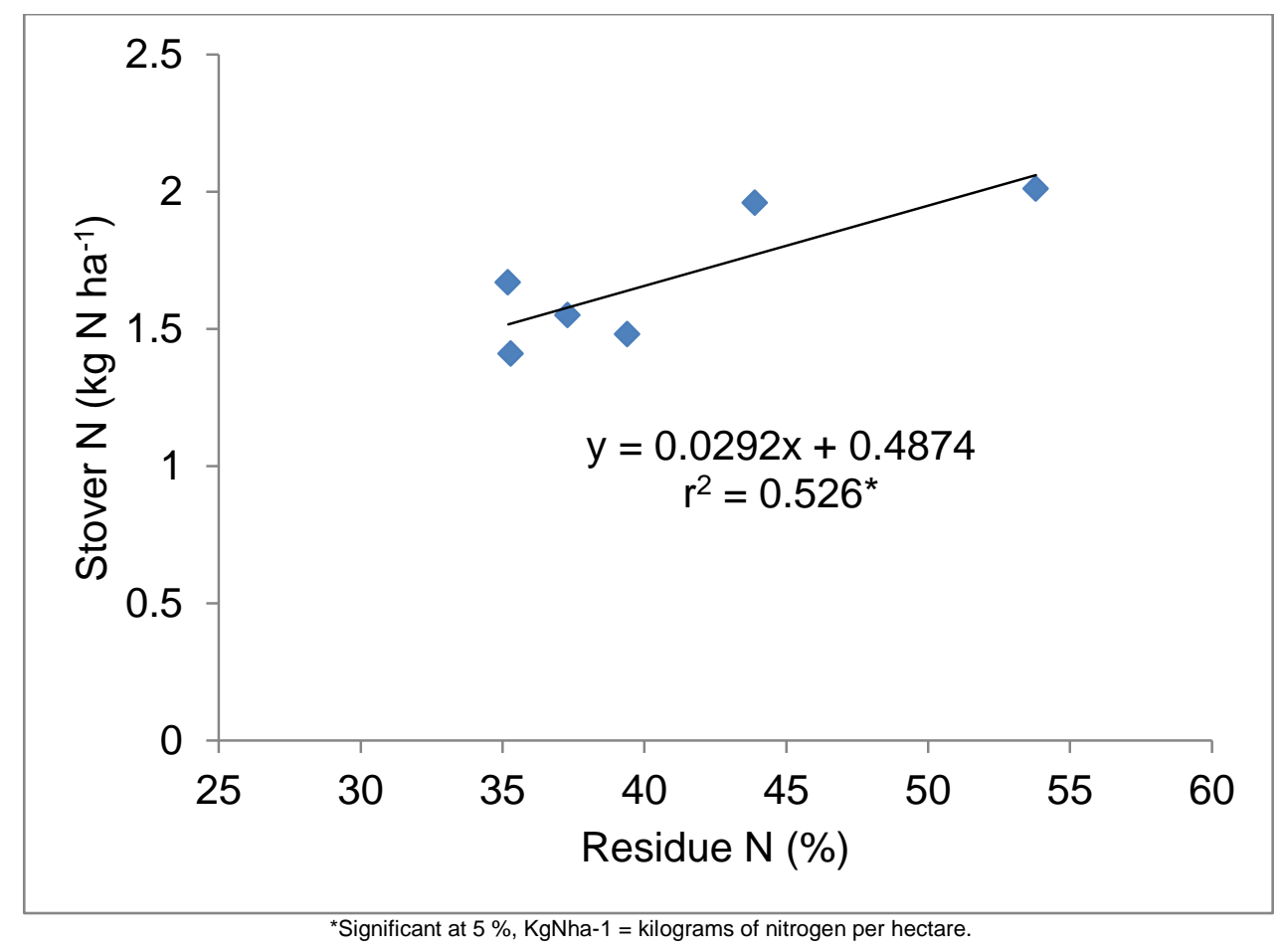

Fig 1.6 Relationship between residue $\mathbf{N}$ and stover $\mathrm{N}$ as affected by spacing arrangement in 2007 . 


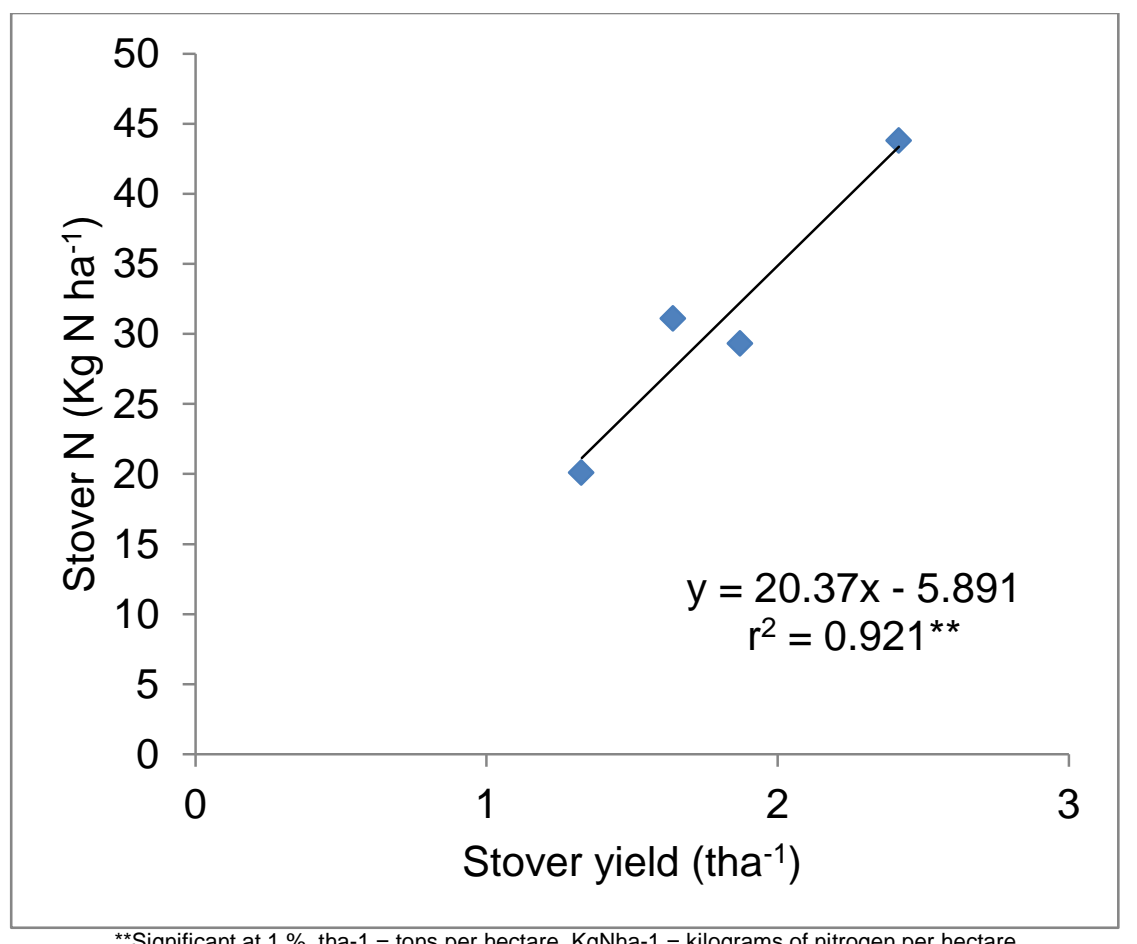

${ }^{* *}$ Significant at $1 \%$, tha- 1 = tons per hectare, $\mathrm{KgNha}-1$ = kilograms of nitrogen per hectare.

Fig1.7 Relationship between stover yield and stover $\mathrm{N}$ as affected by variety in 2006.

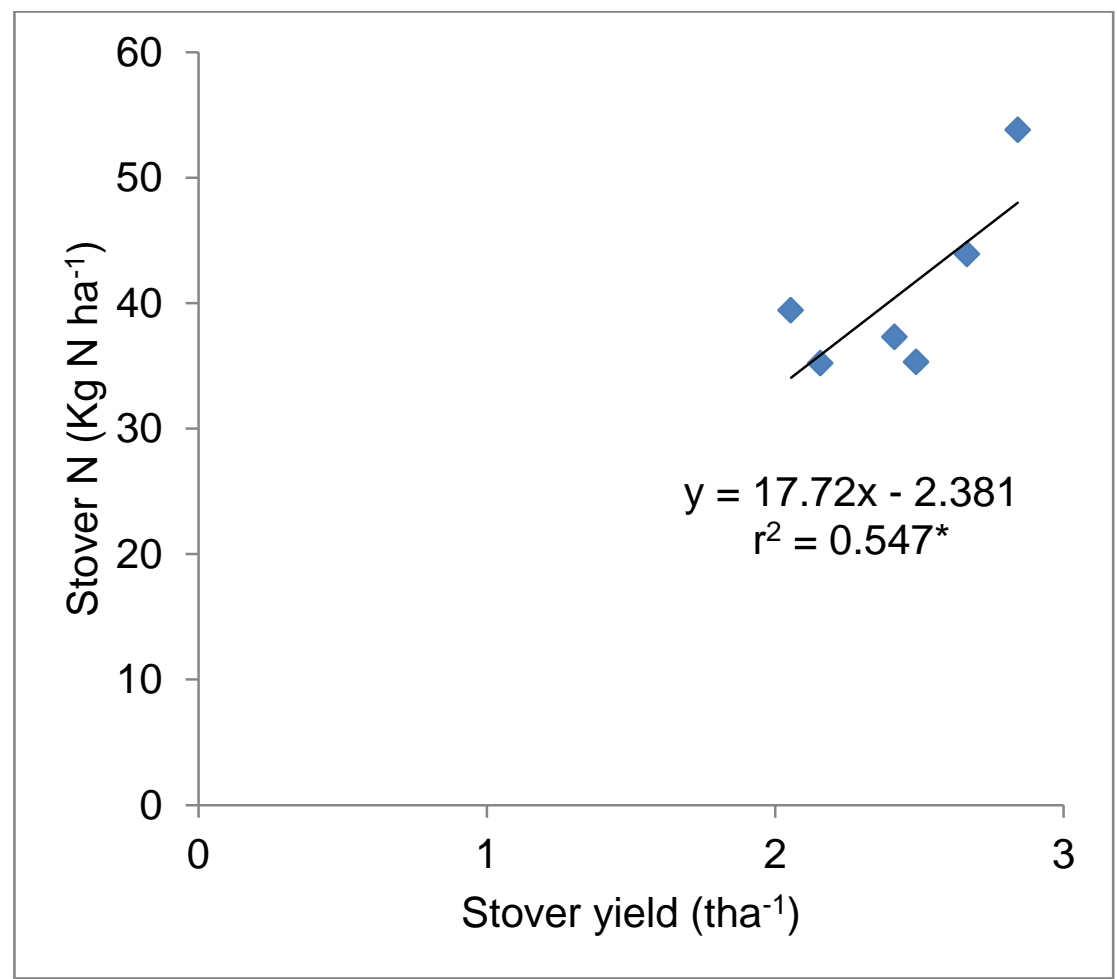

${ }^{*}$ Significant at $5 \%$, tha-1 = tons per hectare, $\mathrm{KgNha}-1=$ kilograms of nitrogen per hectare.

Fig 1.8 Relationship between stover yield and stover $\mathrm{N}$ as affected by variety in 2007 . 


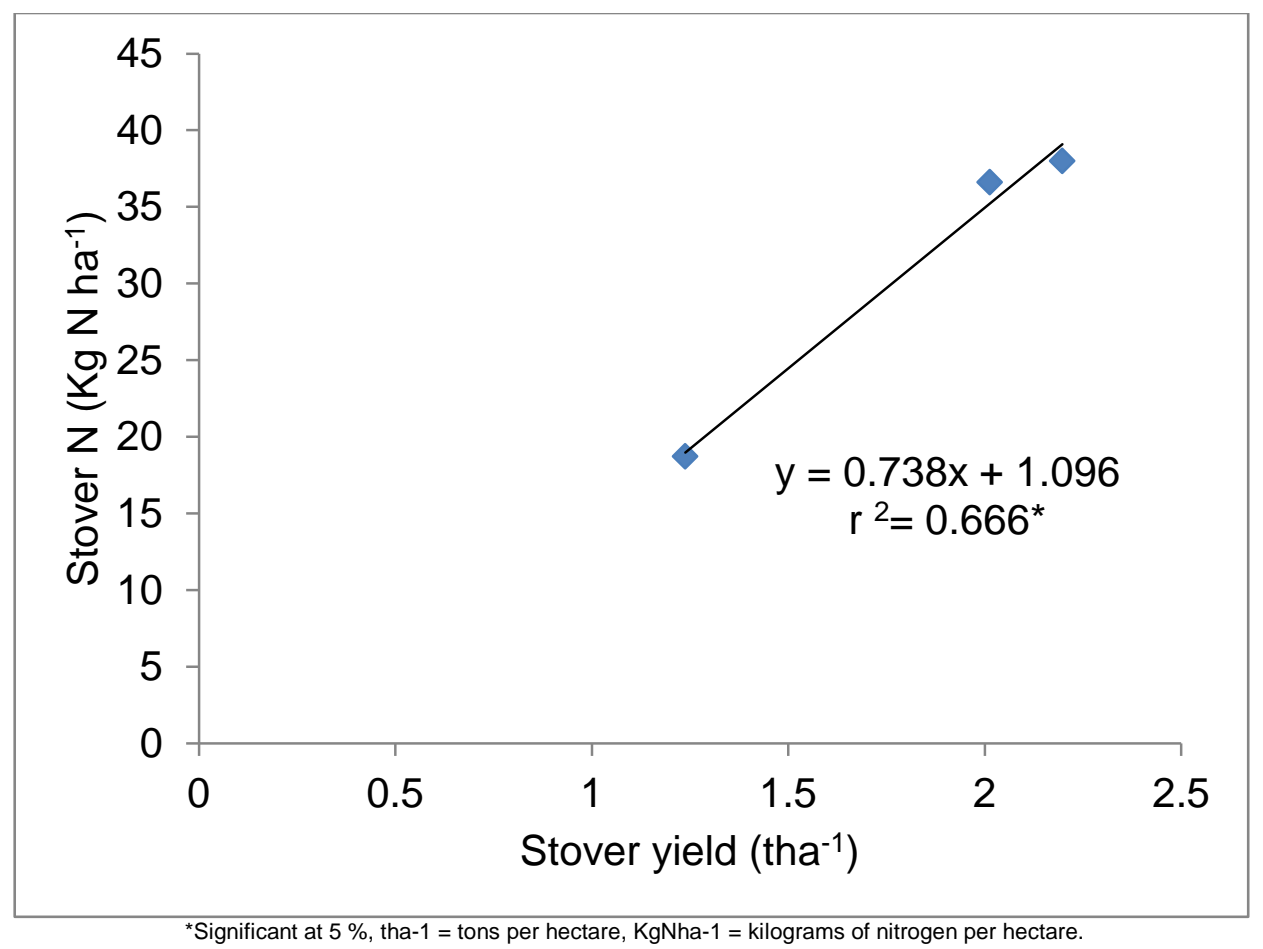

Fig 1.9 Relationship between stover yield and stover $\mathrm{N}$ as affected by spacing arrangements in 2006.

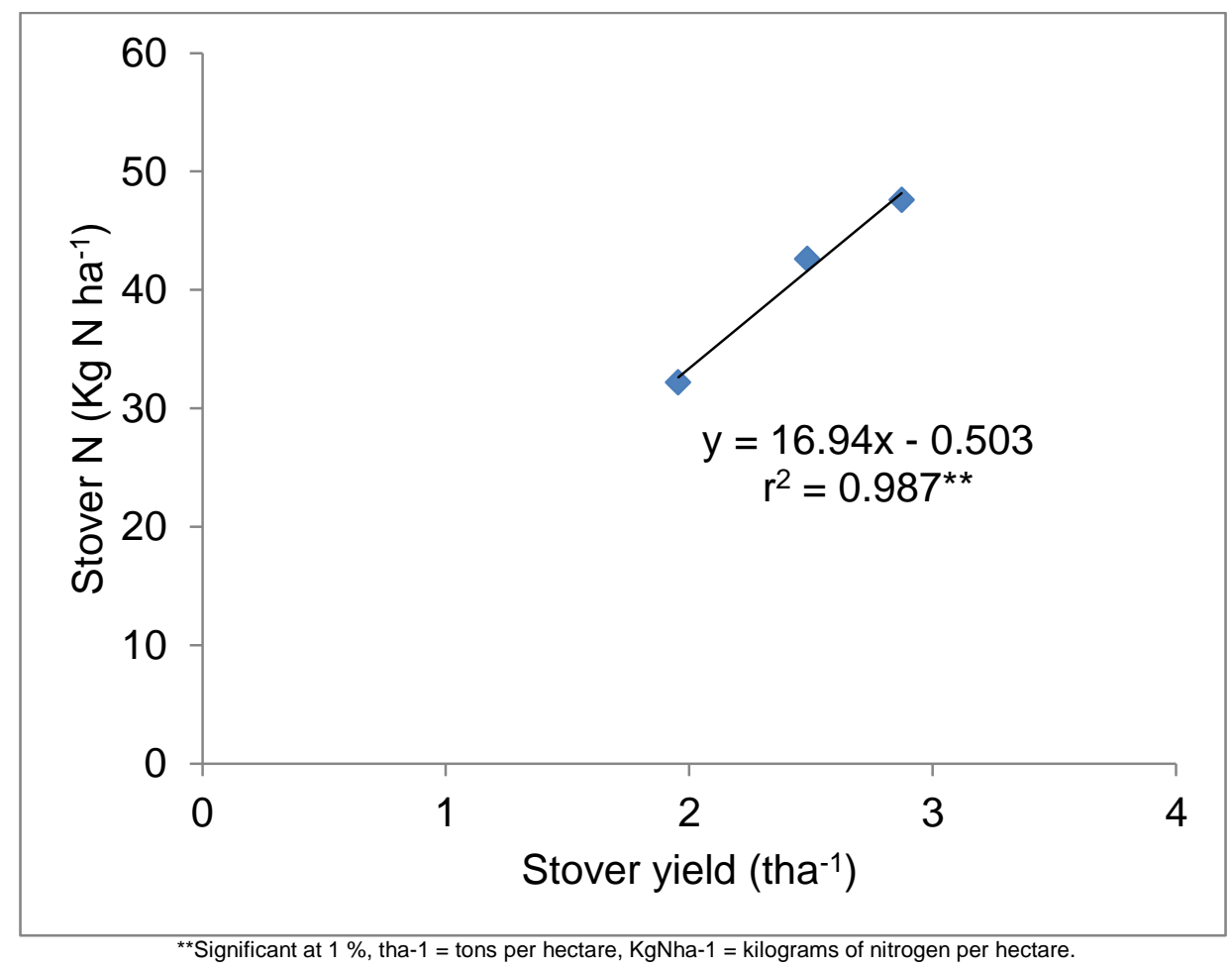

Fig 1.10 Relationship between stover yield and stover $\mathrm{N}$ as affected by spacing arrangements in 2007. 


\section{DISCUSSION}

Plant stand, number of branches and nodules: The absence of variation in plant stand by the groundnut varieties probably relates to similar genetic response to the environment Since differences in plant stand in groundnut varieties under similar environmental conditions has been attributed to mainly genetic factors (Ahmad and Mohammad, 1997). The relatively higher plant stand observed in the Adepa and Nkosuor varieties in 2006, and Manipintar in 2007 can be attributed to plant factors since all the varieties experienced similar environmental conditions although these were not significantly different from the other varieties. The general poor plant stand observed for all the varieties and spacing arrangement could have been caused by the high temperatures and insufficient soil moisture shortly after seeding (ICCRISAT, 1994).

Although there were no variation in the number of branches among the varieties in and spacing both years, the mean of varietal treatments was reduced by $13.9 \%$ in 2007 , probably as a result of the drought experienced during the early part of the season. The similar numbers of branches recorded by the varieties suggest that the varieties did not differ significantly in terms of the intrinsic plant factors controlling the trait. These intrinsic plant factors were not significantly subject to influence by the environment, resulting similar number of branches when the varieties were established under different spacing arrangements. Similar results were reported by Kang Young Kil et al., (1988) working with soya bean. This observation conflicts with the findings of Andrade et al., (2002) who reported increasing number of branches with increasing row widths.

The lack of differences in the number of nodules with regard to the varieties could have been as result of the insufficient numbers of the compatible native Rhizobia (Giller, 2001) since the land was left fallow after cereal cultivation. Again, the similarities in nodule numbers in both seasons with respect to spacing arrangement suggest that plant spacing did not exert significant effects on the process of nodulation.

Plants shoot dry matter: The increase in plant shoot dry matter (gplant $^{-1}$ ) from 4-8 WAP was consistent with the growth pattern of groundnut. The differences in dry matter observed in both years could be attributed to varietal factors that led to some varieties achieving higher rates of photosynthesis, thereby accumulating more dry matter under the same conditions, supporting earlier findings of Ahmad and Mohammad (1997), Gouri et al., (2005) and Bharud and Pawar (2005). In both years, wide spacing arrangement resulted in higher plant shoot dry matter later in the season probably because of lesser competition for growth resources compared to the close spacing arrangements. The poor performance of the close spacing arrangements later in the season can be attributed to early competition and subsequent depletion of growth resources by the high density crop, coupled with the effects of mutual shading which reduced photosynthetic rates, resulting in lower shoot dry matter. Similar results have been reported by Bulson et al., (1987), and Hauggaard-Nielsen et al., (2001) in bean and peabased intercropping systems respectively.

Percent residue, seed and total nitrogen: Following the pattern of nodulation, no differences were observed in the allocation of nitrogen to residue and seed by varieties in 2006 and by spacing treatments in 2006 and 2007. The relatively lower precipitation received in 2006 could therefore have been the cause of this observation since moisture restriction has been reported by Bado et al., (2006) to inhibit nodulation and nitrogen fixation. The exceptional performance of the Nkosuor variety in 2007 was probably because of conditions favouring growth, which might have supported its genetic potential to assimilate and allocate higher amount of nitrogen both to the residue and seed. This characteristic places Nkosuor among a group of legumes which can play an important role in sustainable subsistence farming systems and it fits well into what Ghosh et al., (2007) referred to as an 'ideal' legume.

Stover yield and nitrogen: Differences in stover yield observed among the varieties were largely as a result of the varying genetic potential to attain different sizes in the same environment at maturity. Closely spaced treatments supported smaller shoot dry matter $\left(\right.$ gplant $\left.^{-1}\right)$. However, the reduced dry matter plant ${ }^{-1}$ was more than compensated for by the additional plants $\mathrm{m}^{-2}$, resulting in a higher stover yield compared to wide spacing arrangements. The higher stover yield values observed in 2007 can be attributed to more available moisture and sufficient nutrient uptake that encouraged vegetative growth, leading to bigger plants and higher stover yield. Such a situation in groundnut however usually occurs at the expense of reproductive growth (Schilling and 
Gibbons, 2002). The lower stover yield obtained in 2006 can be explained by the work of Banerjee et al., (2005) who reported significant reduction in stover yield with decreasing soil moisture availability. Stover $\mathrm{N}\left(\mathrm{kg} \mathrm{N} \mathrm{ha}^{-1}\right)$ is influenced by the amount of crop residue as well as $\mathrm{N}$ concentration in the residue. Therefore, varieties and spacing arrangements that recorded significant stover yields also resulted in significant stover $\mathrm{N}$ in both years. Some stover $\mathrm{N}$ values obtained from this study were consistent with earlier reports of $60 \mathrm{Kg} \mathrm{N}^{-1}$ (Ghosh et al., 2007) and 54-58 $\mathrm{KgNha}^{-1}$ (Hedge and Dwevidi, 1993). Stover $\mathrm{N}$ of other treatments however, were well below that reported by these studies, probably due to environmental factors controlling nitrogen concentration in the residue and plant size at maturity that determines the overall stover yield.

Correlations: The positive relationship between residue $(\mathrm{N} \%)$ and stover $\mathrm{N}\left(\mathrm{Kg} \mathrm{N} \mathrm{ha}^{-1}\right)$ as well as between stover yield (tha ${ }^{-1}$ ) and stover $\mathrm{N}$ confirms the earlier reports by Bell et al., (1993) and Boote et al., (1992) indicating that groundnut plant dry matter and nitrogen content are positive and strongly correlated to the stover $\mathrm{N}$. This suggest that activities including spacing arrangements that will lead to increases in either or both stover yield and residue $\mathrm{N}$ can potentially increase the overall amount of nitrogen left behind by groundnut cultivation.

\section{CONCLUSION}

Based on the results of this study, it can be concluded that the groundnut varieties fixed varying amounts of nitrogen through symbiotic relationships with resident Rhizobia under similar environmental conditions. Therefore, Jenkaar, giving higher stover $\mathrm{N}$ ( $\mathrm{kg} \mathrm{N} \mathrm{ha}{ }^{-1}$ ) would be considered as having the potential to leave more nitrogen in the soil for the succeeding non-legume crop(s) if grown in a rotation. The SP1 spacing arrangement produced very large amounts of crop stover, resulting in higher stover $\mathrm{N}$. Therefore, Jenkaar established using the SP1 spacing arrangement would give the best results and it is of great potential for further research and use by low external input smallholder production systems in the Guinea savanna zones.

\section{ACKNOWLEDGEMENTS}

The authors are indebted to Mr. Atakurah K. Williams, SARI for assisting us with laboratory analysis of plant and soil samples. We also wish to thank Mr. Bawah Inusah and Mr. Moses Laar for their invaluable assistance.

\section{REFERENCES}

Ahmad, N. and Mohammad, R (1997). Evaluation of promising groundnut (Arachis hypogaea) varieties for yield and other characters. Crop and Soil Sc. Pp.251.

Andrade, F. H., Calvino, P., Cirilo, A., and Barbieri, P (2002). Yield responses to narrow rows depend on increased radiation interception. Agron J. 94:975-98.

Bado, B. V., Bationo, A. and Cescas, M. P (2006). Assessment of cowpea and groundnut contributions to the soil fertility and succeeding legume yields in the Guinea zone of Burkina Faso (West Africa). Biol. Fertile. Soils, 43:171-176.

Banerjee, K., Sounda, G. and Mandal, A (2005). Effects of different level of irrigation and cobalt on growth and nodulation of summer groundnut (Arachis hypogaea L.). Journal of Interacademicia 9(2): 235-241.

Bell, M.J., Wright, G.C. and Harch, G (1993). Environmental and agronomic effects on the growth of four peanut cultivars in a subtropical environment. II. Dry matter partitioning. Exp. Agric29 (4): 491-501.

Boote K.J., Jones J.W. and Singh P (1992). Modeling growth and yield of groundnut. In: Nigam S.N. (ed.), Groundnut - A Perspective. International Crops Research Institute for the Semi- Arid Tropics, Patancheru, India, pp. 331-343.

Bharud, R. W. and Pawar, M. R (2005). Physiological basis of yield variation in groundnut varieties in under summer conditions. Journal of Maharashtra Agricultural Universities 30(1): 100-102.

Bulson, H.A.J., Snaydon, R.W., and Stopes, C.E (1997). Effects of plant density on intercropped wheat and field beans in an organic farming system. J. Agric. Sci. 128:59-71.

Francis, C. A (1986). Multiple cropping systems. Macmillan, New York. 378pp.

Giller, K. E (2001). Nitrogen fixation in tropical cropping systems. 2nd Edition. CABI, Wallingford, UK. 405pp.

Ghosh P. K., Bandyopadhyay, K. K. Wanjari, R. H. Manna M. C., Misra, A. K. Mahonty, M. and Subba R. A (2007). Legume effect for enhancing productivity and nutrient use efficiency in major cropping systems-An Indian perspective: A review. Journal of Sustainable Agriculture. Vol 30 (1). p59-86.

Ghosh, P. K., Ramesh, P., Bandypadhyay, K. K., Tripathi, A. K., Hati, K. M., Misra, A. K., and Archarya, C. L (2004a). Comparative effectiveness of cattle manure, poultry manure, phosphocompost and fertilizer-NPK on three cropping systems in Vertisols of semi arid 
Tropics. I. Crop yields and system performance. Bioresource Technology, 95: 73-83

Gomez, A. A. and Gomez, K. A (1984). Statistical procedures for Agricultural research. $2^{\text {nd }}$ ed. John Wiley and Sons. New York. 680 pp.

Gouri, V., Reddy, D. R. and Rao, S. B. S. N (2005). Effects of weather parameters on total DM production and partitioning of Rabi groundnut (Arachis hypogaea L.). Journal of Research ANGRAU 33(1): 1-5.

Hanssen, A. P (1994). Symbiotic nitrogen fixation of crop legumes: achievements and perspectives. Center for Agriculture in the Tropics, Germany. 115pp.

Hauggaard-Nielsen, H., Ambus, P. and Jensen, E. S (2001). Interspecific competition, $N$ use and interference with weeds in pea-barley intercropping. Field Crops Res. 70:101-109.

Hedge, D. M. and Dwivedi, B. S (1993). Integrated nutrient supply and management as a strategy to meet nutrient demand. Fertilizer Research, 38(12): 49-59.

ICRISAT (1994). ICRISAT West African Programs' annual report, 1993. Niger: ICRISAT.

Kang Y. K., Ming, K., Cho N. and Park Y. M (1998). Effects of planting date and plant density on growth and yield of soyabean in Cheju Island. Korean Journal of crop Science, 43(1):44-48.
Linderman, W. C. and Glover, C. R (2008). Nitrogen fixation by legumes. College of Agriculture and Home Economics. New Mexico State University. 129 pp.

Nair, K. P. P., Patel, U. K., Singh, R. P., and Kaushuk, M. K (1979). Evaluation of legume intercropping in conservation of fertilizer nitrogen in maize culture. Journal of Agricultural Science (Camb.), 93(1): 189194.

Nambiar, P. T. C. and Dart, P. J (1980). Studies on nitrogen fixation by groundnut at ICRISAT. In: Proceedings of the international conference on groundnuts, 13-17 Oct. 1980. ICRISAT centre, India pp110-124.

Rwamugira, W. P. and Massawe, R. D (1990). Groundnut/maize intercrop: effect of spatial arrangement on yield and its components. Pages 149153 in proceedings of the fourth Regional Groundnut Workshop for Southern Africa, 19-23 March 1990, Arusha, Tanzania. Patancheru, A. P. 502324 India: ICRISAT

Schilling, R and Gibbons, R (2002). Groundnut. The Tropical Agriculturist. Translated by $S$ Chater and revised by Gibbons, R. Nigam, S. and Chater, S.

Toomsan, B., MacDonagh, J. F., Limpinuntana, V. and Giller, K. E (1995). Nitrogen fixation by groundnut and residual benefits to rice in farmers' fields in Northeast Thailand. Plant and Soil. 175: 45-56. 